Review Paper http://ajol.info/index.php/ijbcs http://indexmedicus.afro.who.int

\title{
Gloriosa, a source of colchicine: review article
}

\author{
Itefa Degefa ALEMU* and Tolessa Muleta DABA \\ Bule Hora University, Faculty of Natural and Computational Sciences, Biology Department, P. O. Box 144, \\ Bule Hora, Ethiopia. \\ *Corresponding author; E-mail: ittafaadaggafaa@gmail.com, tolessan2012@gmail.com
}

\begin{abstract}
The objective of this review is to assess the importance of Gloriosa superba as a source of colchicine and action to taken on the conservation of the plant in Ethiopian. Gloriosa superba L. is an important plant distributed in different countries which is known by its valuable chemical called colchicine. Due to this, the crop is marketable worldwide especially exported from India. It is also used for various ailments treatment both traditionally and in modern pharmacology. In plants, it is used to inhibit cell division and form chromosome duplication (polyploidy) which is very useful for changing agronomic traits of crops. So, this chemical has implication in mutation breeding of crop species where the traits are modified as chromosome number is duplicated. However, in Ethiopia, little is known on its ethno-botanical importance and there is no study showing its chemical constituent and preservation mechanisms. There is Gloriosa superba in Ethiopia, but attention wasn't given to it and colchicine chemical which is expensive in market was not extracted for different purpose. A great attention is required from botanists, biotechnologists, policy makers and conservationists to scale up the values of this plant.

(C) 2016 International Formulae Group. All rights reserved.
\end{abstract}

Keywords: Tissue culture, antimitotic, conservation, medicinal plants, Ethiopia

\section{INTRODUCTION}

Gloriosa species, these mi-woody herbaceous climbers belonging to the family Liliaceae is a major highly valuable plant which is distributed in Africa from East Senegal to Ethiopia, Somalia and South Africa. Gloriosa superba is one of the endangered species which is a medicinal plant (Badola, 2002). It is an erect or climbing annual herb growing up to $3 \mathrm{~m}$ high. Flowers are showy, orange to red or sometimes yellow in color. It was found in the wild on natural fences a decade back, but now it has been domesticated for economic gain in as much as all parts of the plant having medicinal value. It is now widely distributed throughout the tropics, and worldwide as a pot plant (Ghosh et al., 2002). In nature, less seed germination with poor viability is responsible for its diminishing population size. The poor propagation coupled with over-exploitation companies has put this plant into very threatened by the local population as well as pharmaceutical species (Yadav et al., 2012) since it is one of the major medicinal plants.

The genus Gloriosa is a native to tropical Africa and is found growing naturally in many countries of tropical Asia including Bangladesh, India, Sri Lanka, Malaysia and Myanmar (Ade and Rai, 2009). Gloriosa 
superba is also planted outdoors in the southern United States. In cool temperate countries, it is treated as a greenhouse plant.

In India, it is cultivated for its seeds and tubers which are exported to developed countries for pharmaceutical use. The high medicinal value is due to the presence of many secondary metabolites (Rehana and Nagarajan, 2012). Gloriosa superba L. is generally found in western parts of Tamilnadu and Kerala, India. It is critically endangered plant and has placed it in red data book (Mishra et al., 2011). Muralia and Pathak (2007) reported that glory cultivation may produce 1.5 to 3 quintals of seed, 1.0 to 1.25 quintals of dry rhizomes per hectare, annually in India. In Bangladesh, the plant is naturally found to grow in Sal Forests of Dhaka and Gazipur districts (Hassan and Roy, 2005) and in the Hill Tracts of Chittagong (Biswas et al., 2010).

In Africa, its distribution is from East Senegal to Ethiopia and Somalia, and to South Africa. Gloriosa is national flower emblem of Zambia. There are 11 species in the Ethiopian Flora area (Miege and Sebsebe, 1997). Gloriosa superba (Gloriosa abyssinica) is called 'Yemariam Tsiwa' in Amharicand, Glory Lily in English (Sebsebe, 1997) and 'Hoomaa' in Afan Oromo (Teshome, 2015). It inhabits to Acacia commiphora, Combretum termianlia woodland, in open places in forest edges on well-drained soils, in thickets on roadsides and along ditches, about 400-2500 $\mathrm{m}$ altitudes in most Ethiopian regions (Sebsebe, 1997). The objective of this review is to assess the importance of Gloriosa superba as source of Colchicine.

\section{MARKET VALUE OF GLORIOSA DUE TO COLCHICINE CONTENT}

Production of a stable quality and quantity of these plants is important to growing world market, which make it necessary to breed varieties with high yield and quality (Anandhi and Rajamani, 2013).

In the world market Gloriosa is considered as rich source of colchicines and gloriosine where the main commercial source for colchicine is obtained from two members of the Liliacea, Colchicum species and Gloriosa superba as they have higher colchicine content than the other species (Finnie and Vanstaden, 1991). Since the discovery of colchicine in it, its commercial importance has increased as it has a higher content of colchicine (Yoshida et al., 1988).

In India, the seeds are being officially exported through Basic Chemicals, Pharmaceuticals and Cosmetics Promotion Council set up by the Ministry of Commerce. The international market rate of the seed is around $\$ 45 / \mathrm{kg}$ now, although it was around $\$ 30 / \mathrm{kg}$ in 2000 . The annual trade estimated is $100-200$ million tones and the price range is 600-750/kg (Ved, 2007).

So, Gloriosa superba would apparently be a better source of commercial colchicine. Bharathi et al. (2006) reported that from different six species of Gloriosa, the Gloriosa superba contains $0.211 \mathrm{mg} / \mathrm{g}$ followed to Gloriosa palanti exhibited the highest colchicine content $0.342 \mathrm{mg} / \mathrm{g}$, Gloriosa casuariana $(0.246 \mathrm{mg} / \mathrm{g})$ and Gloriosa lutea $(0.294 \mathrm{mg} / \mathrm{g})$.

\section{PARTS OF GLORIOSA AS SOURCE OF COLCHICINE}

The high colchicine content accompanied by prospects of good availability from both wild and cultivated sources make the seeds of Gloriosa superba a potential commercial source of colchicine (Sivakumar and Krishnamurthy, 2002). All parts of this plant are extremely poisonous; especially the tuber. Gupta et al. (2005) reported that seeds and tubers contain valuable alkaloids colchicine as the major constituents. He reported as colchicine content has been estimated to be $0.6 \%$ in seeds where it is $2-5$ times higher than in tubers. However, Finnie and Vanstaden (1991) reported that colchicine levels in Gloriosa superba corms to the level of around $0.9 \%$ and that of a seed is $0.61 \%$. So, the seeds of Gloriosa superba are highly priced in the world market as sources of 
colchicine, a chemical that has been used in the past as a remedy against gout (a disease caused by deposits of uric acid in the joints) (Sivakumar and Krishnamurthy, 2002). Early study of Gloriosa superba revealed that colchicine levels are highest during the initial growth of plant and these levels decline during maturation with a slight increase in alkaloid content when corms become dormant at the end of season. The study of (Chandrawanshi et al., 2015) says the field grown natural plant tubers of Gloriosa contained $0.36 \%$ colchicine whereas one month old and three months old tubers of Gloriosa superba in cultures showed $0.08 \%$ and $0.11 \%$ colchicine respectively. Tubers from six month sold tissue culture raised and acclimatized plantlets in the field contained $0.22 \%$ colchicine.

\section{USES OF GLORIOSA FOR DIFFERENT TREATMENTS}

In humans the Gloriosa superba's seeds are used for relieving rheumatic pain and as a muscle relaxant (Ved, 2007). The rhizome has been reported as abortifacient in early stage of pregnancy and its rhizome starch is reported useful in gonorrhea (Mali et al., 2006). Gloriosa superba used to treat Gout and tumor traditionally in Ethiopia (Hassan and Roy, 2005). Shanmugamet al. (2009) reported that the tubers of Gloriosa superba were found to possess mutagenic properties by Ames Salmonella mutagenicity test due to presence of colchicine. Colchicine has been used as a cytotoxic drug and used in treatment of inoperable carcinoma (Brown, 1945).The tuber powder was effectively used against paralysis, rheumatism, snake bite, insect bites, against lice, intermittent fevers, wounds, anti-fertility, gonorrhea, leprosy, piles, debility, dyspepsia, haemorrhoids, helminthiasis and inflammations (Jana and Shekhawat, 2011). Very recently, G. superba leaf extract has been used for metal nanoparticle synthesis (Gopinathet al., 2014).

\section{TOXICITY OF COLCHICINE}

Colchicine is usually lethal to dividing animal cells, even at low concentration necessary to block mitosis. However, plant cell can survive in a state of colchicine induced mitotic arrest for several days and return to division after colchicine is removed. Plant micro tubes are more resistance to colchicine treatment than vertebrates' microtubules, due to the low affinity of plant tubulin dimers for the drug and they can be completely disrupted by extremely high concentration of colchicine (Morejohn and Fosket, 1991). The effect of colchicine on higher plant cells is time dependent exposure of colchicine for a short time results in disassembly of the interphase microtubule network. The minimum concentration required for mitotic block of animal and plant cells differs by several orders of magnitude. Thus, animal cells are about 100,000 times more sensitive to colchicine than plant cells. Due to its antimitotic properties, colchicine from Gloriosa superba will prevent spindle formation, at metaphase, of dividing cells. So it can be used to artificially induce polyploidy in plants. The chromosomes in the cell continue to divide with no sister cell formation (Evans, 1996) leading to doubling in chromosome number. The advantages of increased chromosome number include production of large flowers or fruit, increased hardiness, increase in size of various organs or change in season of maturity. This was suggested not to be due to higher ploidy level (Evans, 1996) suggested a role of colchicine as an elicitor of secondary product formation.

\section{COLCHICINE FOR PLANT BREEDING}

Colchicine from Gloriosa superba is used in biological and breeding studies to produce polyploidy and in tubulin binding assay as a positive control. Its content is about $0.1-0.8 \%$ colchicine in bulb which is used in plant breeding to induce mutation and polyploidy and also can solve an important problem in fuchsia breeding (Ravindra and Mahendra, 2009). Colchicine is believed to interfere with cell division through its 
disruptive action on mitotic spindle. This inhibition occurs either in directly or indirectly, an example of indirect action would be the activation of enzyme which attacks the spindle while a direct action might involve binding of colchicine to spindle fibers causing them to dissociate in protein subunits. Kumar (1953) reported that fresh extracts from tubers of Gloriosa superba when applied to maize seeds before sowing caused tetraploid sectors in developing roots. Colchicine is a powerful antimitotic agent that blocks or suppresses cell division by inhibiting mitosis, the division of a cell's nucleus. The colchicine extract from six different species of Gloriosa at the concentration of $30 \mathrm{mg} / \mathrm{L}$ shows an inhibition of mitosis in onion root tip comparable with that of standard (Bharathi et al., 2006).

\section{Conclusion}

Gloriosa superba is a plant which has diverse applications. So many experiments done to identify the different parts of this plant and their importance were reported by different scholars in different countries. Even though there is Gloriosa superba in Ethiopia, no such study was conducted and no attempt is done to conserve the plant both by in-situ and ex-situ method. Considering that the plant is a source of very expensive chemical colchicine, no attempt was done to extract the chemical from the plant which indicate as there is information about the importance of the plant in Ethiopia.

\section{COMPETING INTERESTS}

The authors declare that they have no competing interests.

\section{AUTHORS' CONTRIBUTIONS}

The authors equally developed, wrote and edited the article.

\section{ACKNOWLEDGMENTS}

We are grateful for all those who read the article and give us constructive comments and editorial suggestion.

\section{REFERENCES}

Ade R, Rai MK. 2009. Current Advances in Gloriosa superba L. Biodiversitas, 10: 210-214. DOI: http://biodiversitas. mipa.uns.ac.id/D/D1004/D100409.pdf

Anandhi S, Rajamani K. 2013. Analysis of Variability, Correlation and Path Coefficients in Induced Mutants of Glory Lily (Gloriosa superba L.). Global Science Books: 7 pages. DOI: http://www.globalsciencebooks.info/Onli ne/GSBOnline/images/2013/

Badola HK. 2002. Endangered medicinal plant species in Himachal Pradesh. A report on the international workshop on Endangered Medicinal Plant species in Himachal Pradesh organized by G.B. Plant Institute of Himalayan Environment and Development at Himachal Unit. Curr. Sci., 83: 797-798. DOI: http://dx.doi.org/10.1659/MRD-

JOURNAL-D-14-00034.1

Bharathi P, Philomina D, Chakkaravarthi S. 2006. Antimitotic effect of colchicine from six different species of Gloriosa in onion roots (Allium cepa). J. Med. Sci., 6(3): $\quad 420-425 . \quad$ DOI: http://scialert.net/qredirect.php?doi=jms.2 006.420.425\&linkid=pdf

Biswas A, Bari MA, Roy M, Bhadra SK. 2010. Inherited folk pharmaceutical knowledge of tribal people in the Chittagong Hill Tracts, Bangladesh. Indian Journal of Traditional Knowledge, 9: 77-89. DOI: http://nopr.niscair.res.in/bitstream/123456 789/7159/1/IJTK\%209\%281\%29\%207789.pdf

Brown WO.1945. Seed L. Effects of colchicine on human tissue. J. Clin. Pathol., 15: 189-95. DOI: http://www.academia.edu/3690377/Critic al_review_on_medicinally_potent_plant_ species_Gloriosa_superba

Chandrawanshi NK, Jadhav SK, Tiwari KL, Quraishi A. 2015. In vitro Tuberization and Colchicine Content Analysis of Gloriosa superba L. School of Studies in Biotechnology, Pt. RavishankarShukla 
University, Raipur, 492010, India. Biotechnology, 14(3): 142-147. DOI: http://docsdrive.com/pdfs/ansinet/biotech/ 2015/142-147.pdf

Evans WC. 1996. Trease and Evans Pharmacognosy. WB Saunders Company Ltd: London.

Finnie JF, Vanstaden J. 1991. Isolation of colchicine from Sandersonia aurantiaca and Gloriosa superba - variation in the alkaloid levels of plants grown in vivo. Journal of Plant Physiology, 138: 691695.

Ghosh B, Mukherjee S, Jha TB, Jha S. 2002. Enhanced colchicine production in root cultures of $G$. superba by direct and indirect precursors of the biosynthetic pathway. Biotechnol. Lett., 24: 231-234. DOI:http://link.springer.com/article/10.10 23/A:1014129225583.

Gopinath K, Karthika V, Gowri S, Senthilkumar V, Kumaresan S. 2014. Antibacterial activity of ruthenium nano particles synthesized using Gloriosa superba L leaf Extract. J. Nano Struct. Chem. 4(83). DOI: 10.1007/s40097- 0140083-4.

Gupta LM, Rana RC, Raina R, Meenakshi G. 2005. Colchicine content in Gloriosa superba L. SKUAST-J. J. Res., 4: 238241. DOI: $10.5897 / J M P R 12.805$

Hassan AKMS, Roy SK.2005. Micropropagation of Gloriosa superba L. through High Frequency Shoot Proliferation. Plant Tissue Cult., 15: 67$74 . \quad$ DOI: www.banglajol.info/index.php/PTCB/arti cle/download/10238/7575.

Jana S, Shekhawat, GS. 2011. Critical review on medicinally potent plant species: Gloriosa superba. Fitoterapia, 82: 293301. DOI: $10.1016 /$ j.fitote.2010.11.008

Kumar LS. 1953. Doubling of chromosomes induced by Gloriosine isolated from Gloriosa superba Linn. Nature, 171:791792. DOI: http://www.ijpbs.net/vol3/issue-2/bio/36.pdf
Mali RG, Hudiwale JC, Gavit RS, Patil DA, Patil KS. 2006. Herbal abortifacient used in North Maharashtra. Nat Prod Radia, 5: 315-318. DOI: http://nopr.niscair. res.in/bitstream/123456789/7959/1/NPR \%205\%284\%29\%20315-318.pdf

Miege, J, Sebsebe D. 1997. Hydrocharitaceae to Arecaceae. In Flora of Ethiopia and Eritrea (vol. 6), Sue E, Sebsebe D, Inga $\mathrm{H}$ (eds); 55-62.

Mishra HS, La PK. 2011. Gloriosa SuperbaAn endangered plant spotted for the first time from forest of Tpchanchi, Hazaribag (Jharkhand), India. Sci. Res. Reporter., 1(2): 61-64.

Morejohn LC, Fosket DE. 1984. Inhibition of microtubule polymerization in vitro by the phosphoricamide herbicide amiprophosmethyl. Science, 224: 874876. DOI: http://www.ncbi.nlm. nih.gov/pmc/articles/PMC159359/pdf/10 50309.pdf

Muralia S, Pathak AK. 2007. Gloriosa superba L. Medicinal and Aromatic Plants: Cultivation and Uses. Aavishkar Publishers: Jaipur; 153-155.

Ravindra Ade, Mahendra KRai. 2009. Review: Current Advances in Gloriosa superba L. Biodiversitas, 10(4): 211-215. DOI: 10.13057/biodivd100409

Rehana B, Nagarajan N. 2012. Phytochemical screening for active compounds in Gloriosa superba leaves and tubers. Journal of Pharmacognosy and Phytochemical Research, 4(1): 17-20. DOI: http://www.wjpps.com/ download/article/1417782476.pdf

Sebsebe D. 1997. Hydrocharitaceae to Arecaceae. Flora of Ethiopia and Eritrea, 6: 184-185. DOI: http://snm.ku.dk/forskning/internationalt_ nationalt_samarbejde/flora_ethiopia/

Shanmugam H, Rathinam R, Chinnathambi A, Venkattesan T. 2009. Antimicrobial and mutagenic properties of the root tubers of G. superba Linn. Kalihari. Pak J Bot., 41(1): $\quad$ 293-299. DOI: 
http://www.pakbs.org/pjbot/PDFs/41\%28 1\%29/PJB41\%281\%29293.pdf

Sivakumar G, Krishnamurthy KV. 2002. Gloriosa superba L.: a useful medicinal plant. In Recent progress in medicinal plants: Ethnomedicine and pharmacognosy II, Singh VK, Govil JN, Hashmi S, Singh G (eds). Sci-Tech Publishing LLC: Houston, USA; 465481.

Teshome S. 2015. Diversity, Regeneration, Structure and Uses of Some Woody Species in Borana Forests of Southern Ethiopia: The Case of Yaballo and Arero Forests Center for Environmental Science. Journal of Environment and Earth Science, 5(11): 23. DOI: http://www.iiste.org/Journals/index.php/J EES/article/viewFile/23283/24029
Ved DK. 2007. Demand and supply of medicinal plants in India. Key Findings and Recommendations; 133-134. http://nmpb.nic.in/FRLHT/chapter-10.pdf

Yadav K, Aggarwal A, Singh N. 2012. Actions for ex situ conservation of Gloriosa superba L. - an endangered ornamental cum medicinal plant. J. Crop Sci. Biotech., 15: 297-303. DOI: 10.1007/s12892-012-0045-7

Yoshida K, Hayashi T, Sano K. 1988. Colchicoside in Colchicum autumnale bulbs. Agric Biol Chem., 52: 593-594. DOI: $\quad$ http://ci.nii.ac.jp/els/ 110006323677.pdf?id=ART0008330921 $\&$ type $=$ pdf $\&$ lang $=$ en $\&$ host $=$ cinii $\&$ order no $=\& p p v \_t y p e=0 \& l a n g \_s w=\& n o=14722$ $13866 \& \mathrm{cp}=$ 